\title{
Formulation and Evaluation of Fast Dissolving Tablets of Felodipine
}

\author{
S. Sravani Dr.P.Sailaja, \\ M.Pharm, PhD Research scholar, Au college of Pharmaceutical Sciences Andhra University \\ Visakhapatnam. \\ Au college of Pharmaceutical Sciences,Andhra University,Visakhapatnam.
}

\begin{abstract}
About 40\% of new chemical entities ( NCEs) are lipid soluble and are sparingly soluble in water. So inorder to increase their solubility, bioavailability and dispersibility of the drugs without affecting therapeutic activity of the drug the super disintegrants are used. Felodipine is a BCS class II drug with low solubility and high permeability for which the super disintegrant plantago ovata in the form of mucilage is used to enhance the disintegration, dispersibility and solubility.
\end{abstract}

\section{INTRODUCTION}

Bioavailability of a drug depends in absorption of the drug, which is affected by solubility of the drug in gastrointestinal fluid and permeability of the drug across gastrointestinal membrane. The drugs solubility mainly depends on physico- chemical characteristics of the drug. However, the rate of drug dissolution is greatly influenced by disintegration of the tablet.The drug will dissolve at a slower rate from a non-disintegrating tablet due to exposure of limited surface area to the fluid. Disintegrating agents an important excipient of the tablet formulation, are always added to increase surface area of the tablet fragments and to overcome cohesive forces that keep particles together in a tablet.Disintegrating agent can be added either prior to granulation or prior to compression or at both the processing steps. Extragranular fraction of disintegrant (usually, $50 \%$ of total disintegrant requires) facilitates breakup of tablets to granules and the intragranular addition of disintegrants produces further erosion of the granules to fine particles.

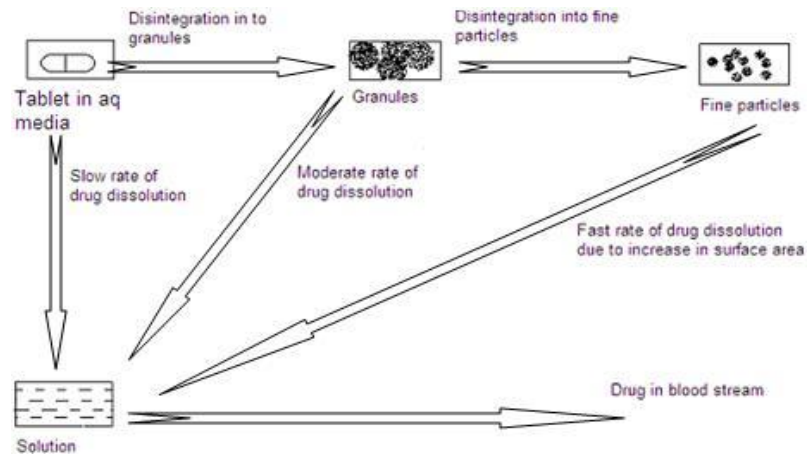

Schematic Representation Of Tablet Disintegration And Subsequent Drug Dissolution Mechanism of tablet disintegration process:

The tablet gets disintegrated into small and fine particles by one or more mechanisms listed below:I.By capillary action

II.By swelling

III.Because of heat of wetting

IV.Due to disintegrating particle/particle repulsive forces

V.Due to deformation

VI.Due to release of gases

VII.By enzymatic action

II. TYPES OF DISINTEGRANTS

List Of Disintegrants 


\begin{tabular}{|c|c|c|}
\hline Disintegrants & Concentration & Inference \\
\hline Starch USP & $5-20$ & $\begin{array}{l}\text { Higher amount is } \\
\text { required, poorly } \\
\text { compressible }\end{array}$ \\
\hline Starch 1500 & $5-15$ & - \\
\hline $\begin{array}{l}\text { Pregelatinized } \\
\text { starch }\end{array}$ & $5-10$ & $\begin{array}{ll}\text { Lubricant } & \\
\text { properties } \\
\text { directly } \\
\text { compressible }\end{array}$ \\
\hline Solka floc ${ }^{(\mathrm{r})}$ & $5-15$ & $\begin{array}{l}\text { Purified } \\
\text { cellulose }\end{array}$ \\
\hline Alginic acid & $1-5$ & Acts by swelling \\
\hline $\mathrm{Na}$ alginate & $2.5-10$ & Acts by swelling \\
\hline $\begin{array}{l}\text { Polyplasdone }^{(\mathrm{r})}(\mathrm{X} \\
\mathrm{L})\end{array}$ & $0.5-5$ & Crosslinked PVP \\
\hline $\begin{array}{l}\text { Amberlite }^{(\mathrm{r})} \text { (IPR } \\
88)\end{array}$ & $0.5-5$ & $\begin{array}{ll}\text { Ion } & \text { exchange } \\
\text { resin } & \\
\end{array}$ \\
\hline $\begin{array}{l}\text { Methyl cellulose, } \\
\text { Na CMC, HPMC }\end{array}$ & $5-10$ & - \\
\hline \multirow[t]{2}{*}{ AC-Di-Sol ${ }^{(\mathrm{r})}$} & $1-3$ & $\begin{array}{l}\text { Direct } \\
\text { compression }\end{array}$ \\
\hline & $2-4$ & Wet granulation \\
\hline
\end{tabular}

Fast dissolving tablets are the need of the hour in the present generation as the people are being involved in too many schedules and also the availability of water is also being a problematic thing. so these tablets can be taken without water as they are designed to undergo pregastric absorption in the saliva bypassing the first pass effect. these tablets are advantageous to all group of people including paediatric and geriatric patients. so for better results use of super disintegrating agents may be used. some examples of commercially available fast dissolving tablets are :

\begin{tabular}{|l|l|l|}
\hline Brand name & Active ingredient & Manufacturer \\
\hline Felden fast melt & Piroxicam & Pfizer.Inc.,NY,USA \\
\hline Maxalt MLT & Rizatriptin & Merck.Co.,NJ,USA \\
\hline Febrectol & Paracetamol & $\begin{array}{l}\text { Prographarm, } \\
\text { Chateauneuf, } \\
\text { France }\end{array}$ \\
\hline Nimulid MDT & Nimesulide & $\begin{array}{l}\text { Panacea,New } \\
\text { Delhi,India }\end{array}$ \\
\hline Romilast & Montelukast & $\begin{array}{l}\text { Ranbaxy lab Ltd, } \\
\text { New Delhi, India }\end{array}$ \\
\hline Pepcid RPD & Famotidine & Merck.Co.,NJ,USA \\
\hline
\end{tabular}

\section{SUPERDISINTEGRANTS}

As day's passes, demand for faster disintegrating formulation. is increased. So, pharmacist needs to formulate disintegrating agents i.e. Superdisintegrants which are effective at low concentration and have greater disintegrating efficiency and they are more effective intragranularly. But have one drawback that it is hygroscopic therefore not used with moisture sensitive drugs. And this superdisintegrants act by swelling and due to swelling pressure exerted in the outer direction or radial direction, it causes tablet to burst or the accelerated absorption of water leading to an enormous increase in the volume of granules to promote disintegration.

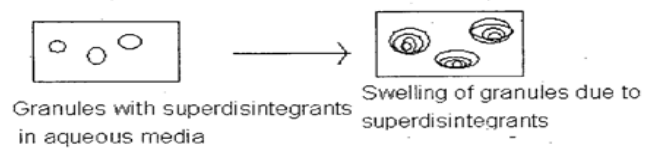

Fig. Mechanism of superdisintegrants by swelling

List Of Superdisintegrants

\begin{tabular}{|l|l|l|l|}
\hline Superdisintegrants & Examples & Mechanism & Inference \\
\hline
\end{tabular}


Formulation And Evaluation Of Fast Dissolving

\begin{tabular}{|c|c|c|c|}
\hline $\begin{array}{l}\text { Crosscarmellose }^{(\mathrm{r})} \\
\text { Primellose }^{(\mathrm{r})} \\
\text { Solutab }^{(\mathrm{r})}\end{array}$ & $\begin{array}{l}\text { Crosslinked } \\
\text { cellulose }\end{array}$ & $\begin{array}{l}- \text { Swells } 4-8 \text { folds } \\
\text { in }<10 \text { seconds. } \\
\text {-Swelling and } \\
\text { wicking both. }\end{array}$ & $\begin{array}{l}\text {-Swells in two } \\
\text { dimensions. } \\
\text {-Direct } \\
\text { compression or } \\
\text { granulation } \\
\text {-Starch free }\end{array}$ \\
\hline 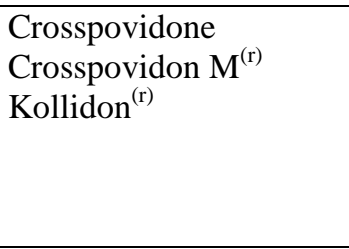 & $\begin{array}{l}\text { Crosslinked } \\
\text { PVP }\end{array}$ & $\begin{array}{l}\text {-Swells very little } \\
\text { and returns to } \\
\text { original size after } \\
\text { compression but } \\
\text { act by capillary } \\
\text { action }\end{array}$ & $\begin{array}{l}\text {-Water insoluble } \\
\text { and spongy in } \\
\text { nature so get } \\
\text { porous tablet }\end{array}$ \\
\hline $\begin{array}{l}\text { Sodium starch glycolate } \\
\text { Explotab }^{(\mathrm{r})} \\
\text { Primogel }^{(\mathrm{r})}\end{array}$ & $\begin{array}{l}\text { Crosslinked } \\
\text { starch }\end{array}$ & $\begin{array}{l}- \text { Swells } 7-12 \\
\text { folds in }<30 \\
\text { seconds }\end{array}$ & $\begin{array}{l}\text {-Swells in three } \\
\text { dimensions and } \\
\text { high level serve } \\
\text { as sustain release } \\
\text { matrix }\end{array}$ \\
\hline $\begin{array}{l}\text { Alginic acid NF } \\
\text { Satialgine }^{(\mathrm{r})}\end{array}$ & $\begin{array}{l}\text { Crosslinked } \\
\text { alginic acid }\end{array}$ & $\begin{array}{l}\text {-Rapid swelling } \\
\text { in aqueous } \\
\text { medium or } \\
\text { wicking action }\end{array}$ & $\begin{array}{l}\text {-Promote } \\
\text { disintegration in } \\
\text { both dry or wet } \\
\text { granulation }\end{array}$ \\
\hline $\begin{array}{l}\text { Soy polysaccharides } \\
\text { Emcosoy }^{(r)}\end{array}$ & $\begin{array}{l}\text { Natural super } \\
\text { disintegrant }\end{array}$ & & $\begin{array}{l}\text {-Does not } \\
\text { contain any } \\
\text { starch or sugar. } \\
\text { Used in } \\
\text { nutritional } \\
\text { products. }\end{array}$ \\
\hline Calcium silicate & & -Wicking action & $\begin{array}{l}\text {-Highly porous, } \\
\text {-light weight } \\
\text {-optimum } \\
\text { concentration is } \\
\text { between } 20-40 \%\end{array}$ \\
\hline
\end{tabular}

Inspite of using super disintegrating agents we have to consider some other factors which may effect the disintegration process and the ultimate absorption and bioavailability of the tablet like the use of binder,lubricant,surfactant,etc. in the optimum and concentrations.

\section{FELODIPINE:}

Felodipine (Plendil) is a calcium antagonist (calcium channel blocker). Felodipine is a dihydropyridine derivative that is chemically described as + ethyl4-(2,3-dichlorophenyl)-1,4-dihydro-2,6-dimethyl-3,5 Pyridinedicarboxylate. It lowers blood pressure by reducing peripheral vascular resistance through a highly selective action on smooth muscle in arteriolar resistance vessels.

\section{CHEMICAL STRUCTURE:}

\section{Properties:}<smiles>CCOC(=O)C1=C(C)NC(C)=C(C(=O)OCC)C1c1cccc(Cl)c1Cl</smiles>

Empirical formula: $\mathrm{C}_{18} \mathrm{H}_{19} \mathrm{Cl}_{2} \mathrm{NO}_{4}$

Felodipine is a slightly yellowish, crystalline powder with a molecular weight of 384.26 . It is insoluble in water and is freely soluble in dichloromethane and ethanol. Felodipine is a racemic mixture. Its melting point is $145^{\circ} \mathrm{C}$.

\section{Category:}

Antiarrhythmic agent 
Antihypertensive agent

Calcium chaiihel blocker

Vasodilator agent

Mechanism of action:

Felodipine is a calcium channel blocker. It reversibly competes with nitrendipine and/or other calcium channel blockers for dihydropyridine binding sites, blocks voltage-dependant calcium currents in vascular smooth muscle and cultured rabbit atrial cells, and blocks potassium-induced contracture of the rat portal vein. By. blocking the calcium channels, felodipine inhibits the influx of extra cellular calcium across the myocardial and vascular smooth muscle cell membranes and result in a decrease of peripheral vascular resistance.

\section{Pharmacokinetics:}

Absorption: Felodipine is an orally administered drug and is almost completely absorbed and undergoes extensive first pass metabolism. The systemic bioavailability is approximately $20 \%$. Mean peak concentration reaches in 2.5 - 5 hrs.

Distribution: The degree of plasma protein binding of felodipine is about $99 \%$.

Half life: 14.1 hours

Bioavailability: 15 - 20

Metabolism: Felodipine has extensive hepatic first pass metabolism. Felodipine is metabolized by CYP3A4.

Storage: Store below $30^{\circ} \mathrm{C}\left(86^{\circ} \mathrm{F}\right)$. Keep container tightly closed. Protect from light.

Adverse Reactions: The most common clinical adverse events reported peripheral oedema and headache. Rarely nausea, dyspepsia and constipation.

Objective:

Main objective of the work is to improve solubility of felodipine and to develop fast disintegrating tablets of felodipine using the natural super disintegrating agent plantago ovata in the form of mucilage (rather than the chemical or synthetic agents) to enhance the oral bioavailability and for faster onset of action.

Calibration curve for the estimation of felodipine in methanol

\begin{tabular}{|l|c|c|}
\hline S.No & $\begin{array}{c}\text { Concentration } \\
(\boldsymbol{\mu} \mathbf{g} / \mathbf{m l})\end{array}$ & Absorbance \\
\hline 1. & 0 & 0 \\
\hline 2. & 5 & 0.0943 \\
\hline 3. & 10 & 0.1825 \\
\hline 4. & 15 & 0.2750 \\
\hline 5. & 20 & 0.3711 \\
\hline 6. & 25 & 0.4729 \\
\hline
\end{tabular}

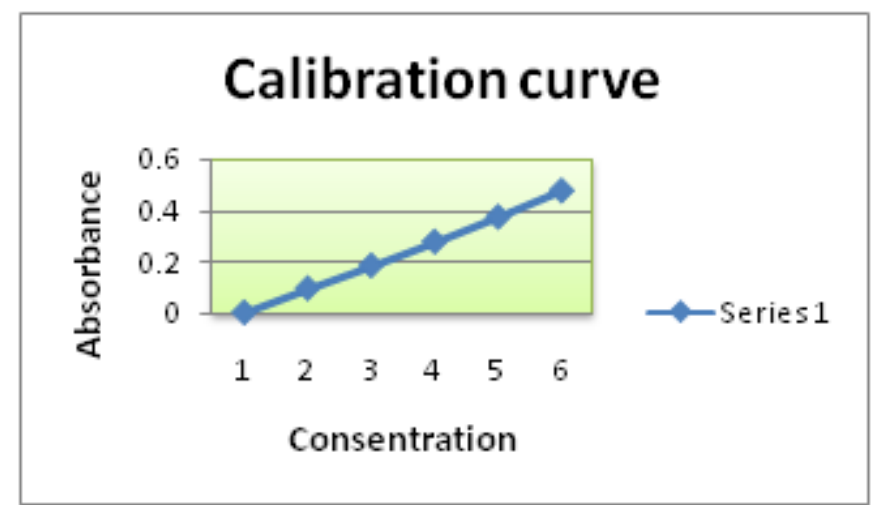

Calibration curve for the estimation of felodipine in methanol

\section{DISCUSSION}

The method obeyed Beer's law in the concentration range of $5-25 \mu \mathrm{g} / \mathrm{ml}$. In order to find out degree of linear relationship correlation coefficient was calculated. It was found to be very near to I which indicates a high degree of correlation. Next it was of interest to establish the mathematical form of linear relationship between the two variables (concentration and absorbance) under consideration and the equation obtained was $\mathrm{y}=$ $0.0188 \mathrm{x}+0.0022$

V.

CONSTRUCTION OF CALIBRATION CURVE OF FELODIPINE

The calibration curve for felodipine was constructed using methanol and $\mathrm{pH} 6.8$ phosphate buffer as solvents. The concentration maximum of felodipine in methanol was found to be $362 \mathrm{~nm} \lambda_{\max }$ (Dong-Han Won et al) and Beer's law was. obeyed in the range of $5-25 \mu \mathrm{g} / \mathrm{ml}$. An UV spectroscopic method based on measurement of absorbance at $362 \mathrm{~nm}$ was used for the estimation of felodipine. 


\section{PREPARATION AND EVALUATION OF FASTDISINTEGRATING TABLETS OF FELODIPINE}

In the present part of work, felodipine fast disintegrating tablets are prepared by direct compression method employing varying concentration of super disintegrant planatgo ovata mucilage. The prepared tablets are evaluated for physical characteristics and drug release studies.

\section{Preparation of Felodipine Fast disintegrating Tablets}

Different felodipine fast disintegrating tablets are prepared using varying concentration super disintegrant planatgo ovata mucilage.

\section{METHOD OF PREPARATION}

1. The raw materials were passed through a screen (40 mesh) prior to mixing.

2. Then Powdered felodipne, was mixed with the other excipients

3. The mixture was then compressed on a tablet machine equipped Formulalor the preparation of fast disintegrating tablets of felodipine

\begin{tabular}{|l|l|l|l|l|}
\hline \multicolumn{1}{|c|}{ Ingredients } & \multicolumn{1}{c|}{$\begin{array}{c}\text { POM } \\
0 \%\end{array}$} & $\begin{array}{c}\text { POM } \\
10 \%\end{array}$ & $\begin{array}{c}\text { POM } \\
15 \%\end{array}$ & $\begin{array}{c}\text { POM } \\
20 \%\end{array}$ \\
\hline Felodipine & $10 \mathrm{mg}$ & $10 \mathrm{mg}$ & $10 \mathrm{mg}$ & $10 \mathrm{mg}$ \\
\hline Planatgo ovata mucilage & $0 \mathrm{mg}$ & $10 \mathrm{mg}$ & $15 \mathrm{mg}$ & $20 \mathrm{mg}$ \\
\hline Talc & $2 \mathrm{mg}$ & $2 \mathrm{mg}$ & $2 \mathrm{mg}$ & $2 \mathrm{mg}$ \\
\hline Magnicium stearate & $2 \mathrm{mg}$ & $2 \mathrm{mg}$ & $2 \mathrm{mg}$ & $2 \mathrm{mg}$ \\
\hline MCC & $86 \mathrm{mg}$ & $76 \mathrm{mg}$ & $71 \mathrm{mg}$ & $66 \mathrm{mg}$ \\
\hline Total weight $(\mathrm{mg})$ & 100 & 100 & 100 & 100 \\
\hline
\end{tabular}

\section{Evaluation of Powder Properties of Tablet}

The quality of tablet, once formulated by rule, is generally dictated by the quality of physicochemical properties of blends. The various characteristics of blends tested are as given below:

\section{Angle of Repose}

The angle of repose was determined by the funnel method suggested by Newman. Approximately $5 \mathrm{gm}$ of powder was poured through a glass funnel from a height of 6 centimeter onto a level bench top. The angle that the side of the conical heap made with the horizontal plane was recorded as the angle of repose.

Angle of repose is determined by the following formula

Tan $\theta @=h / r$

Where $\theta 0=$ Angle of repose

$\mathrm{h}$ and $\mathrm{r}$ are the height and radius of the powder cone.

\begin{tabular}{|c|l|}
\hline Angle of. Repose( $\mathbf{0})$ & \multicolumn{1}{|c|}{ Type of flow } \\
\hline$<25$ & Excellent \\
\hline $25-30$ & Good \\
\hline $30-40$ & Fairpassable \\
\hline$>40$ & Very poor \\
\hline
\end{tabular}

\section{Bulk Density}

Aparent bulk density (pb) was determined by placing preseived drug excipients blend into a graduated cylinder and measuring the volume $(\mathrm{Vb})$ and weight $(\mathrm{M})$ " as it is."

$\mathrm{pb}=\mathrm{M} / \mathrm{Vb}$

\section{Tapped density}

The measuring cylinder containing a known mass of blend was tapped for a fixed time. The minimum volume $(\mathrm{Vt})$ occupied in the cylinder and the weight $(\mathrm{M})$ of the blend was measured. The tapped density (pt) was calculated using following formula.

$\mathrm{pt}=\mathrm{M} / \mathrm{Vb}$

\section{Evaluation test for fast disitegrating tablets of felodipine}

\section{Weight variation}

Twenty tablets from each batch were individually weighed individually on an analytical balance. The average weight and standard deviation were calculated and the results are shown in the table. Standard values are shown in the table given below. 


\begin{tabular}{|c|l|l|}
\hline \multirow{2}{*}{$\begin{array}{c}\text { Maximum \% } \\
\text { difference allowed }\end{array}$} & \multicolumn{2}{|c|}{ Average Weight of tablets (mg) } \\
\cline { 2 - 3 } & USP XXVU & \multicolumn{1}{c|}{ IP 2007 } \\
\hline 10 & 130 or less & 80 or less \\
\hline 7.5 & $130-324$ & $80-250$ \\
\hline 5 & More than 324 & More than 250 \\
\hline
\end{tabular}

Tablet hardness

Hardness of the tablet of each formulation was measured using Monsanto Hardness tester. One tablet from each batch were tested for hardness.

\section{Friability}

This test was performed using Roche friabilator. Three tablets were weighed and placed in the friabilator that revolves at a speed of $25 \mathrm{rpm}$, dropping those tablets at a) distance of 6 inches with each revolution.

The tablets were rotated in the friabilator for at least 4 minutes.

Friability is calculated by the formula

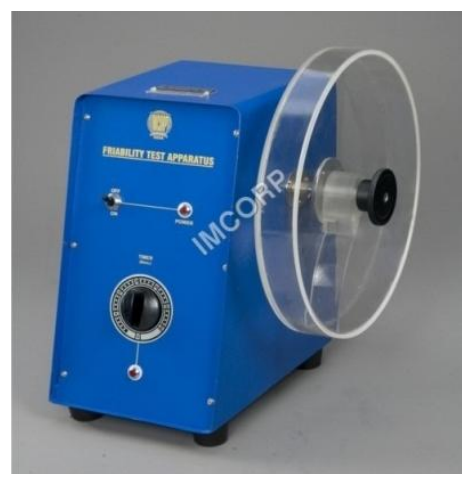

Friability apparatus

$\%$ loss in weight $=(\mathrm{wl}-\mathrm{w} 2 / \mathrm{wl}) \times 100$

Where, w1 = Initial weight of tablets before the test

w2 = Final weight of tablets after the test

\section{In vitro disintegration time}

In vitro disintegration time was performed by apparatus specified in USP at $50 \mathrm{rpm}$. Phosphate buffer $\mathrm{pH} 6.8$, $900 \mathrm{ml}$ was used as disintegration medium, and the temperature of which maintained at $37 \pm \quad 2{ }^{\circ} \mathrm{C}$ and the time in second taken for complete disintegration of the tablet with no palpable mass remaining in the apparatus was measured in seconds. Limits (IP 2007) all the tablets should disintegrate in less than 3 minutes.

\section{Drug release studies}

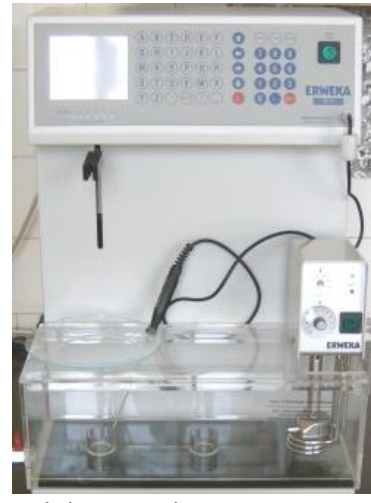

Disintegration apparatus

Drug release from different tablets was studied by carrying out the dissolution test in the following manner. The test was performed in Lab India dissolution test apparatus in $900 \mathrm{~m} 1$ of $\mathrm{pH} 6.8$ phosphate buffer and rpm of 75 by maintaining the temperature of the bath at $37 \pm 0.5^{\circ} \mathrm{C}$. Sink condition was maintained every time. Samples of $5 \mathrm{~m} 1$ were taken and during each sampling replacement was made immediately with $5 \mathrm{ml}$ of the buffer solution.

\section{Comparision of flow properties of different tablet blends}




\begin{tabular}{|l|l|l|l|}
\hline \multicolumn{1}{|c|}{ Properties } & Angle of repose & Bulk density & Tapped density \\
\hline $\operatorname{POM}(0 \%)$ & & & \\
\hline $\operatorname{POM}(10 \%)$ & 29.05 & 0.510 & 0.617 \\
\hline $\operatorname{POM}(15 \%)$ & 28.56 & 0.501 & 0.609 \\
\hline $\operatorname{POM}(20 \%)$ & 31.32 & 0.515 & 0.632 \\
\hline
\end{tabular}

Flow Characteristics

It is a very well known that poorly flowing powders or granulations present several difficulties to the compression process. The values of pre-ᄀcompression parameters evaluated (shown in table) are within prescribed limits and indicated good free flowing property. Angle of repose values between 23 and 30 show that the powder exhibited good flow properties.

\section{Hardness, Friability and Weight variation of fast disintegrating Tablets}

The hardness, friability and weight variation of formulated tablets are described in Table. To be acceptable by USP standards, the weight variation tolerance for uncoated tablets must be $7.5 \%$ or less. All the tablets have weight variation values within the limits. The friability obtained confirmed the suitability of direct compression technology to these powders. Good uniformity in drug content was found among different tablets.

Weight variation:

\begin{tabular}{|l|l|l|l|}
\hline \multicolumn{1}{|c|}{ of SSG } & $\begin{array}{c}\text { Accepted } \\
\text { variation }\end{array}$ & Actual weight & Weight variation \\
\hline POM I & \pm 5 & 98 & 2 \\
\hline POM II & \pm 5 & 96 & 4 \\
\hline POM III & \pm 5 & 103 & 3 \\
\hline POM IV & \pm 5 & 101 & 1 \\
\hline
\end{tabular}

Friability:

\begin{tabular}{|c|l|l|c|}
\hline Percentage & $\begin{array}{c}\text { Initial weight } \\
(3 \text { tablets })\end{array}$ & Final weight & $\%$ Error \\
\hline 0 & $296 \mathrm{mg}$ & $294 \mathrm{mg}$ & $0.68 \%$ \\
\hline 10 & $300 \mathrm{mg}$ & $298 \mathrm{mg}$ & $0.67 \%$ \\
\hline 15 & $306 \mathrm{mg}$ & $304 \mathrm{mg}$ & $0.65 \%$ \\
\hline 20 & $302 \mathrm{mg}$ & $300 \mathrm{mg}$ & $0.66 \%$ \\
\hline
\end{tabular}

\section{Wetting time}

This can be used as another confirmative test for the evaluation of fast disintegrating tablets, since the dissolution profiles of the tablets depend on the wetting followed by disintegration. Wetting times decreased with the increasing levels of concentration of super disintegrants.

\section{Disintegration time}

The most important property that needs to be optimized in development of fast disintegrating tablets is the disintegration time of the tablets. In the present study all the tablets disintegrated in $\leq$ S 105 seconds. It was observed that the disintegration time of the tablets decreased as the concentration of POM increased.

\section{Drug content:}

\begin{tabular}{|l|l|l|}
\hline Formulation & Disintegration time & Wetting time \\
\hline SSG $(0 \%)$ & 92 seconds & 111 seconds \\
\hline SSG $(10 \%)$ & 60 seconds & 91 seconds \\
\hline SSG $(15 \%)$ & 52 seconds & 62 seconds \\
\hline SSG $(20 \%)$ & 45 seconds & 50 seconds \\
\hline
\end{tabular}

Ten tablets were weighed and powdered, a quantity of powder equivalent to $1 \mathrm{mg}$ of Felodipine was transfer-red to a $50 \mathrm{ml}$ volumetric flask and $1 \mathrm{ml}$ methanol is added for solubilizing it better and volume is made upto $50 \mathrm{ml}$ using pH 6.8 phosphate buffer is added. Then stoppered flask shaked vigorously for 15 minutes. then the liquid is filtered. The felodipine content was determined by measuring the absorbance at $362 \mathrm{~nm}$ after appropriate dilution with water. The drug content was calculated using the standard calibration curve. The mean percent drug content was calculated as an average of three determinations. 


\begin{tabular}{|l|l|}
\hline Formulation & Drug content\% \\
\hline POM I & $99.41 \%$ \\
\hline POM II & $98.87 \%$ \\
\hline POM III & $99.56 \%$ \\
\hline POM IV & $99.82 \%$ \\
\hline
\end{tabular}

\section{DISSOLUTION STUDIES}

The influence of super disintegrating agents on the dissolution profiles of felodipine fast disintegrating tablets are shown in the given table. T/z values decreased with the increase in the level of plantago ovata mucilage. As the concentration of disintegrating agent is increased, the dissolution rates increased.

\begin{tabular}{|c|c|c|c|c|}
\hline \multirow{2}{*}{$\begin{array}{c}\text { Time in } \\
\text { mins }\end{array}$} & \multicolumn{5}{l|}{ \%elease } \\
\cline { 2 - 5 } & POM I & POM II & POM & POM \\
\hline 0 & 0 & 0 & 0 & 0 \\
\hline 5 & 35.17 & 45.34 & 57.27 & 65.82 \\
\hline 10 & 46.87 & 56.23 & 70.97 & 78.16 \\
\hline 15 & 70.56 & 72.79 & 85.76 & 92.39 \\
\hline 20 & 87.22 & 89.45 & 91.12 & 94.26 \\
\hline 30 & 91.13 & 91.32 & - & - \\
\hline
\end{tabular}

\section{SUMMARY AND CONCLUSIONS}

Many active pharmaceutical ingredients have excellent therapeutic efficacy but show poor oral bioavailability because of poor aqueous solubility. Pharmaceutical researchers use various techniques to overcome the problem of poor aqueous solubility and formulation of fast disintegrating tablets is one of the promising techniques available which is simple and effective. The current pharmaceutical research has drawn much attention on fast dissolving dosage forms due to their rapid onset of action and better acceptability among different age groups and other patients in emergency conditions. The main objective of this work is to improve solubility of felodipine and to develop fast dissolving tablets of felodipine using natural super disintegrating agents to enhance the oral bioavailability and for faster onset of action.

From the evaluation studies the following conclusions can be drawn

- The faster disintegration of tablets with plantago ovata mucilage may be attributed to its rapid capillary activity and pronounced hydration.

- The dissolution studies showed a initial rapid release ( in first 5 minutes), followed by a slow and steady release later.

- The dissolution rate followed first order kinetics.

- T50 values decreased with the increase in.the level of plantago ovata mucilage concentrations..

In the present part of the work, effect of super disintegrant in varying concentrations on the drug release of felodipine from tablets was evaluated. Four different formulations of felodipine were prepared by direct compression method employing varying concentrations of super disintegrant (plantago ovata mucilage). These tablets were evaluated for hardness, friability, weight variation, disintegration time, wetting time, drug content and drug release studies.

1 All the formulations exhibited good hardness, friability and weight variation. The drug content uniformity of all the tablets is also within the limits.

2. The formulations POM 3 and POM 4 showed faster disintegration and wetting time compared to other formulations.Thus the results indicated that the dissolution profiles of the tablets are in agreement with the disintegration time values observed. All the tablets disintegrated in less than 3 minutes. Thus the objective of preparing fast disintegrating tablets is achieved.

\section{CONCLUSION}

It is concluded that fast dissolving tablets of felodipine prepared with $20 \%$ of super disintegrant showed decrease in disintegration time, wetting time and dissolution time and we estimate that this formulation is the best among the other formulations which contain a lesser concentration of super disintegrant.

\section{SCOPE FOR FURTHER WORK}

An attempt may be made to improve the disintegration of other poorly soluble drugs. An attempt may be done to improve the solubility of insoluble drugs. Other such methods to improve dissolution characteristics are complexation with complexing agents and size reduction, use of surfactants. By the formulation of the disintegrating tablets, bioavailability of the drug can be increased to a remarkable extent. 


\section{REFERENCES}

[1] Blychert E. (1992). "Felodipine pharmacokinetics and plasma concentration vs effect relationships". Blood Press Suppl. 2: 1-30.

[2] Jawad Kiani, Sardar Z Imam (October 30 2007). "Medicinal importance of grapefruit juice and its interaction with various drugs". Nutr J. 6 (33): 33.. Retrieved 2008-04-09.

[3] Hinz B, Auge D, Rau T, Rietbrock _S, Brune K, Werner U. Simultaneous determination of felodipine and three of . its metabolites in human plasma by high-performance liquid chromatography. Biomed Chromatogr. 2003;17:268-75. [PubMed]

[4] Legrand E. felodipine in the management of inflammatory pain. Exp Opin Pharmacother. 2004;5:134757.

[5] Yong CS, Oh YK, Lee KH, Park SM, Park YJ, Gil YS, et al. Trials of clear felodipine- loaded soft capsules with accelerated oral absorption in human subjects. Int J Pharm. 2005;302:78ᄀ83. [PubMed]

[6] Martin A, editor. Physical pharmacy. 4th ed. Philadelphia: Lippincott Willams and Wilkins; 1993. pp. $324-62$.

[7] Schiermeier S; Schmidt PC. Fast dispersible ibuprofen tablets. Eur J Pharm, Sci. 2002;15:295-305. [PubMed] .

[8] ' Mizumoto T, Masuda Y, Yamamoto T, Yonemochi E, Tarada K. Formulation design of a novel fastdisintegrating tablet. Int J Pharm. 2005;306:83-90. [PubMed]

[9] Patrick K, Sang KW. US Patent 5631 023. Method of making freeze-dried dosage form. 1997

[10] Chang RK, Guo X, Burnside B, Couch R. Fast-dissolving tablets. Pharm Technol. 2000;24:52-8.

[11] Takao M, Yoshinori M, Muneo F. Intrabuccally dissolving compressed mouldings and production process thereof. 1996 US patent 5576014. 